Tomasz Grzegorz Grosse

ORCID: 0000-0002-7270-8900

Wydział Nauk Politycznych i Studiów Międzynarodowych

Uniwersytetu Warszawskiego

DOI: $10.19195 / 2450-274 X .4 .3$

\title{
Trzy logiki geopolityczne brexitu $^{*}$
}

Abstrakt: Artykuł ukazuje proces brexitu w perspektywie geopolitycznej. W tym celu przedstawiono trzy, jak się wydaje, dominujące logiki geopolityczne widoczne wśród elit brytyjskich, a następnie ukazano je w kolejnych etapach działań poprzedzających referendum z 2016 r. i występujących w trakcie negocjacji Zjednoczonego Królestwa z Brukselą, dotyczących wyjścia tego państwa ze struktur UE.

Słowa kluczowe: brexit, geopolityka, Unia Europejska

\section{Three geopolitical logics of Brexit}

Abstrakt: The purpose of the article is to show the Brexit process in a geopolitical perspective. To this end, three seemingly dominant geopolitical logics, visible among the British elite, were presented, and then they were examined in the consecutive stages of political activities preceding and following the referendum of 2016, including the negotiations of the United Kingdom with Brussels regarding the exit of that country from European Union structures.

Keywords: Brexit, geopolitics, European Union

\section{Wprowadzenie}

Proces brexitu, czyli wychodzenia Zjednoczonego Królestwa Wielkiej Brytanii i Irlandii Północnej z Unii Europejskiej (UE), można interpretować z wielu perspektyw naukowych. Wśród nich należy wymienić geopolitykę. Termin „geopolityka" pojawił się w naukach społecznych w XIX w. Jego interpretacje na-

* Publikacja powstała w ramach projektu badawczego „O ekonomicznych podstawach supremacji geopolitycznej" finansowanego ze środków Narodowego Centrum Nauki, nr 2015/17/B/HS5/00486 realizowanego w ISPPAN. 
wiązują do dwóch głównych szkół w stosunkach międzynarodowych: realizmu i liberalizmu. Geopolityka w ujęciu klasycznym, tj. pochodzącym z XIX w., jest rozumiana jako rywalizacja mocarstw o władzę $\mathrm{i}$ terytorium lub o władzę w wymiarze geograficznym ${ }^{1}$. Jest to interpretacja bliska realistycznej szkole w stosunkach międzynarodowych. Skupia się ona na największych państwach mających centralne znaczenie dla kształtowania ładu międzynarodowego, a także koncentruje na uwarunkowaniach zewnętrznych tej rywalizacji, tj. dotyczących relacji między poszczególnymi mocarstwami, a mniej na uwarunkowaniach wewnętrznych panujących w poszczególnych krajach. Ważnym założeniem szkoły realistycznej jest przekonanie o istnieniu „obiektywnych” interesów geopolitycznych, które można określić także „racją stanu” danego państwa. Jest ona konsekwencją zewnętrznych czynników strukturalnych i geograficznych występujących na arenie międzynarodowej. $\mathrm{W}$ ujęciu realizmu uwarunkowania wewnętrzne mogą mieć znaczenie wyłącznie w kontekście formowania potencjału danego państwa, ale nie np. dla kształtowania „subiektywnych” interpretacji na temat interesów geopolitycznych.

Naukowcy wskazują kolejne etapy prowadzenia analiz geopolitycznych ${ }^{2}$. W pierwszej połowie XIX w. skupiały się na rywalizacji (lub kooperacji) między głównymi mocarstwami europejskimi, które zajmowały centralną pozycję w ówczesnym ładzie międzynarodowym. Jednocześnie obejmowały ekspansję kolonialną tych mocarstw oraz eksploatację obszarów peryferyjnych jako ważnych źródeł ich potęgi. Dlatego głównym podziałem geopolitycznym było kryterium cywilizacyjne oddzielające europejskie centrum od peryferii. W połowie XIX w., w dobie wzmacniania państw narodowych i rozkwitu nacjonalizmu, główne podziały geopolityczne dotyczyły $\mathrm{z}$ jednej strony poszczególnych europejskich mocarstw, z drugiej zaś rozróżnienia między cywilizowaną Europą a podrzędnymi i eksploatowanymi regionami świata ${ }^{3}$. Kulminacja tego podejścia miała miejsce w latach 30. XX w. i podczas drugiej wojny światowej. Później główny podział geopolityczny znaczony był różnicami ideologicznymi między kapitalistycznym i demokratycznym Zachodem a blokiem państw socjalistycznych ${ }^{4}$.

Pokłosiem klasycznej analizy geopolitycznej było uwypuklenie roli narodowej wspólnoty politycznej. Racja stanu lub interes geopolityczny określonego państwa był odnoszony do całej wspólnoty, a więc nie do poszczególnych interesów partykularnych lub grupowych ${ }^{5}$. Nie był także rozumiany jako agregacja intere-

${ }^{1}$ Por. C. Flint, Introduction to Geopolitics, New York-London 2012, s. 31, 39; G.Ó Tuathail, General Introduction. Thinking Critically about Geopolitics, [w:] The Geopolitics Reader, red. G.Ó Tuathail, S. Dalby, P. Routledge, London-New York 2006, s. 1-14 (1); D. Cowen, N. Smith, After Geopolitics? From the geopolitical social to geoeconomics, „Antipode” 41, 2009, nr 1, s. 23.

2 J. Agnew, Geopolitics. Re-visioning World Politics, London-New York 2003, s. 86-93.

3 Ibidem, s. 93-101.

${ }^{4}$ Ibidem, s. 102-112.

${ }^{5} \mathrm{Na}$ temat definicji racji stanu por. E. Sadowski, Racja stanu w polityce zagranicznej państwa, [w:] Wstęp do teorii polityki zagranicznej państwa, red. R. Zięba, Warszawa 2004, s. 137-141; K. Łastawski, Polska racja stanu po wstąpieniu do Unii Europejskiej, Warszawa 2009, s. 14-23. 
sów cząstkowych na poziomie ogólnokrajowym. Interes geopolityczny państwa (i danej wspólnoty politycznej) był przede wszystkim rezultatem uwarunkowań zewnętrznych. Kluczowe dla tego podejścia są płynące z zewnątrz ograniczenia narodowej suwerenności, podmiotowości lub swobodnego realizowania interesów (racji stanu). Innymi słowy, brak autonomii lub podmiotowości, płynąca z zewnątrz zależność polityczna (w tym np. regulacyjna) lub gospodarcza mogą być traktowane jako znaczące kryterium geopolityczne. Jest to przy tym istotna cecha podejścia realistycznego, która kontrastuje z interpretacją szkoły liberalnej.

W ujęciu liberalnym duże znaczenie dla formowania interesów mają uwarunkowania wewnętrzne, $w$ tym dominujące idee polityczne, jak również deliberacja polityczna dotycząca interpretacji sytuacji strategicznej. Finalna ocena interesów geopolitycznych nie jest więc „obiektywna” i nie jest wyłącznie pochodną uwarunkowań zewnętrznych. Jest raczej rezultatem presji najbardziej wpływowych interesów gospodarczych i społecznych lub powstaje w wyniku debaty publicznej na temat polityki zagranicznej danego państwa. Liberalne podejście do geopolityki wiąże się ze „sposobem widzenia świata”, a więc dominującą ideologią polityczną lub paradygmatem politycznym występującym w danej społeczności. Skupia się na „nadrzędnej strategii” (ang. grand strategy) oraz mechanizmach jej konstruowania w polityce wewnętrznej. Wspomniana strategia jest wprawdzie kształtowana w odniesieniu do określonej sytuacji międzynarodowej, w tym również uwarunkowań geograficznych ${ }^{7}$, niemniej dla liberałów kontekst terytorialny oraz sytuacja międzynarodowa nie zawsze mają decydujące znaczenie w interpretacji interesów geopolitycznych. Niekiedy w omawianym podejściu teoretycznym główną rolę odgrywają całkiem inne uwarunkowania, np. społeczne, ekonomiczne lub ideologiczne. Tak jest w przypadku geopolityki feministycznej i alterglobalistycznej ${ }^{8}$. Ponadto dodatkowym argumentem liberałów jest teza o kształtowaniu globalnych relacji gospodarczych i politycznych oraz związanych z tym współzależności, które osłabiają wcześniejsze znaczenie geografii (a tym samym klasyczne rozumienie geopolityki).

Podejście liberalne rewiduje także historyczne przykłady geopolityki klasycznej. Uznaje m.in., że celem geopolitycznym elit państwowych w XIX w. było nie tylko zdobycie przewagi w relacjach międzynarodowych, lecz także wzmacnianie potencjału i struktur wewnętrznych. Obejmowało wzmacnianie siły krajowej gospodarki i innych zasobów o zastosowaniu militarnym oraz dotyczyło konsolidacji społeczeństwa w obrębie struktur państwowych, m.in. na podstawie ideologii nacjonalistycznej. Zatem „konstruowanie narodu”, czyli stabilnej oraz zintegrowanej wspólnoty politycznej w ramach danego mocarstwa, miało duże znaczenie dla jego siły geopolitycznej na arenie międzynarodowej. Elementem tych zabiegów,

${ }^{6}$ C. Flint, op. cit., s. 33.

7 Por. C.S. Gray, G. Sloan, Why Geopolitics?, [w:] Geopolitics, Geography and Strategy, red. C.S. Gray, G. Sloan, London-Portland 1999, s. 1-11.

${ }^{8}$ C. Flint, op. cit., s. 33, 40. 
poza ideami nacjonalistycznymi, mogło być krzewienie demokracji, praw obywatelskich i przywilejów socjalnych (początkowo dla żołnierzy i ich rodzin oraz weteranów wojennych, a później dla wszystkich obywateli). Stąd określenie „geopolityka socjalna" dla uwypuklenia tych procesów ${ }^{9}$.

W niniejszym artykule geopolityka jest definiowana przede wszystkim w odniesieniu do ujęcia realistycznego. Kluczowe znaczenie dla moich wywodów ma geopolityka rozumiana w sposób klasyczny jako rywalizacja mocarstw (europejskich i światowych) o władzę. Interesy geopolityczne odnoszę przede wszystkim do racji stanu określonej wspólnoty politycznej. W przypadku Unii Europejskiej takie wspólnoty istnieją na poziomie państw członkowskich. Na szczeblu europejskim nie wykształciła się jeszcze podobnego rodzaju wspólnota. Nie ma więc ani europejskiej suwerenności, ani racji stanu. Ma to fundamentalne konsekwencje dla zrozumienia interesów geopolitycznych na Starym Kontynencie, wyjaśnia bowiem przewagę interesów narodowych oraz deficyt myślenia geopolitycznego w skali ogólnoeuropejskiej. Nawet jeśli politycy francuscy i niemieccy wspominają o europejskiej suwerenności ${ }^{10}$, można domniemywać, że mają na myśli wizję rozwoju UE (i jej polityki zewnętrznej) zgodną z interesami Francji i Niemiec. Duże znaczenie dla mojego rozumienia geopolityki ma kwestia ograniczania narodowej suwerenności (podmiotowości lub autonomii) ze strony zewnętrznych uwarunkowań, takich jak te bezpośrednio związane z integracją europejską (prawo UE, rosnąca rola instytucji ponadnarodowych, np. Komisji Europejskiej lub TSUE). W mojej analizie pojawia się interpretacja polityczna racji stanu Wielkiej Brytanii, co nawiązuje do liberalnego postrzegania geopolityki. Jednak w dalszym ciągu kluczowe znacznie dla procesu brexitu wydają się mieć uwarunkowania zewnętrzne i podstawowe dylematy strategiczne z tym związane, m.in. to, czy lepiej być w UE, czy poza nią - bez umowy lub z umową wynegocjowaną przez rząd Theresy May w listopadzie $2018 \mathrm{r}$. Istotne dla tego procesu były zwłaszcza zapisy wspomnianej umowy, na której kształt wpływała przede wszystkim silniejsza w tych rozmowach strona, zewnętrzna wobec Zjednoczonego Królestwa, a więc UE.

$\mathrm{W}$ artykule zamierzam zbadać trzy logiki myślenia geopolitycznego, które można zaobserwować w odniesieniu do brexitu:

- Po pierwsze, że suwerenność i racja stanu Zjednoczonego Królestwa są $\mathrm{w}$ coraz większym stopniu ograniczane przez procesy integracji europejskiej. Takie myślenie dużej części brytyjskich elit politycznych i społeczeństwa było przyczyną najpierw rosnącego dystansu wobec procesów integracyjnych, a następnie legło u podstaw decyzji o opuszczeniu UE. Logika geopolityczna tego założenia polega na tym, że poczucie mocarstwowości lub choćby tylko podmiotowości geopoli-

${ }^{9}$ Szerzej D. Cowen, N. Smith, op. cit., s. 22-48.

10 Macron defends the idea of European sovereignty, European Parliament, ref.: 20180411IPR01517, Brussels 17.04.2018; Merkel: EU states must prepare to hand national sovereignty over to Brussels, „Canada Free Press” 24.11.2018, https://canadafreepress.com/article/merkel-eu-states-must-prepare-to-hand-national-sovereignty-over-to-brussels (dostęp: 27 grudnia 2018). 
tycznej Zjednoczonego Królestwa nie mogło być w pełni zrealizowane poprzez oddziaływanie na kierunki dalszej integracji europejskiej, lecz było raczej przez te procesy coraz bardziej ograniczane, przynajmniej w opinii części elit politycznych.

- Po drugie, że tylko tzw. twardy brexit, a więc wyjście bez umowy z UE, umożliwia zrealizowanie pierwotnych założeń brexitu, a więc odzyskania podmiotowości i suwerenności geopolitycznej. $Z$ tego punktu widzenia znacznie gorszym rozwiązaniem byłaby zgoda na umowę wynegocjowaną przez premier Theresę May, która nakazywała przyjmowanie regulacji UE i oznaczała jurysdykcję Trybunału Sprawiedliwości UE (TSUE) bez możliwości wpływu na te regulacje i bez swobody zawierania porozumień gospodarczych z państwami trzecimi. Takie rozwiązanie było więc postrzegane jako jeszcze większe ograniczenie geopolityczne niż pełnoprawne członkostwo w UE. W takiej sytuacji brexit nie miał sensu, prowadząc do pogorszenia sytuacji geopolitycznej Zjednoczonego Królestwa.

- Po trzecie, że lepiej być pełnoprawnym członkiem UE, w tym dysponującym prawem głosu nad regulacją europejską, aniżeli być tylko związanym z rynkiem wewnętrznym, a więc przyjmować regulacje unijne i podlegać jurysdykcji TSUE, ale bez prawa głosu nad europejskimi regulacjami. Takie podejście było widoczne zwłaszcza u tych polityków i części społeczeństwa, którzy uznawali brexit za coraz mniej opłacalny geopolitycznie, co powodowało m.in. domaganie się kolejnego referendum w sprawie brexitu.

Wymienione logiki geopolityczne w części się uzupełniają, a w części są konkurencyjne. Oznaczają, że pełnoprawne członkostwo w UE było kwestionowane z przyczyn geopolitycznych, ale jeszcze gorzej postrzegano umowę wynegocjowaną przez Theresę May. Z perspektywy brytyjskich interesów od tej umowy lepsze byłoby albo „odwrócenie” brexitu (np. w drodze ponownego referendum), albo wybranie scenariusza „twardego” brexitu. Dlatego też Zjednoczone Królestwo Wielkiej Brytanii i Irlandii Północnej w trakcie negocjacji zmierzało coraz bardziej w kierunku wyjścia z UE bez umowy. Pod względem geopolitycznym takie rozwiązanie było najlogiczniejsze, skoro w 2016 r. społeczeństwo zdecydowało o opuszczeniu Unii. Takie rozstrzygnięcie było również wynikiem mało elastycznego podejścia strony europejskiej do negocjacji, w tym konsekwentnego wykluczania możliwości zmiany umowy wynegocjowanej między stronami w listopadzie $2018 \mathrm{r}$.

\section{Przyczyny}

Wśród przyczyn brexitu najczęściej wymienia się ryzykowną decyzję Davida Camerona o referendum w sprawie dalszego członkostwa Zjednoczonego Królestwa w UE albo niewystarczające ustępstwa strony unijnej w trakcie negocjacji z Wielką Brytanią przed referendum z 2016 r. ${ }^{11}$ Niemniej warto spojrzeć na głęb-

11 Por. A. Glencross, Why the UK Voted for Brexit. David Cameron's Great Miscalculation, London-New York 2016; D.A. Green, Brexit. What Everyone Needs to Know, Oxford-New York 2019. 
sze przyczyny brexitu, w tym także te o charakterze geopolitycznym. Nawiązują one do pierwszej logiki geopolitycznej, a mianowicie wzbierającego przez lata poczucia dużej części elit brytyjskich, że postępy integracji europejskiej ograniczają brytyjską suwerenność i autonomię geopolityczną.

Naukowcy dowodzą, że Wielka Brytania od początku swojej obecności we wspólnotach była zdystansowana wobec postępów integracji ${ }^{12}$. Duża część zarówno elit brytyjskich, jak i społeczeństwa odrzucała ideę „ever closer Union”. W praktyce oznaczało to niezgodę na postępy integracji rozumiane jako odbieranie władzy narodowym wspólnotom demokratycznym i przesuwanie jej w coraz większym stopniu do instytucji europejskich, w tym również technokratycznych, które postrzegano jako niemające odpowiedniej legitymacji demokratycznej ${ }^{13}$. Dla Brytyjczyków szczególnie istotne znaczenie miało to, że tak dużą władzę nad ich krajem zyskała Komisja Europejska i Trybunał Sprawiedliwości UE. Uważali także, że przynajmniej w części obie te instytucje przekraczają ten zakres kompetencji, który zgodziły się przekazać im w traktatach państwa członkowskie ${ }^{14}$. Tym samym zwiększały swoją władzę bez odpowiedniego mandatu ze strony demokratycznych wspólnot narodowych. Taki sposób zarządzania uznawali za niedemokratyczny, a także ograniczający suwerenność Wielkiej Brytanii. Dodatkowym czynnikiem była rosnąca liczba decyzji i regulacji europejskich przyjmowanych $\mathrm{w}$ wyniku głosowania większościowego. Wielka Brytania tylko do pewnego stopnia mogła wpływać na kierunek tych regulacji zgodnie z własnymi interesami. Musiała iść na kompromisy, najczęściej wobec Niemiec i Francji, które w coraz większym stopniu kształtowały kierunki regulacji unijnej.

W ten sposób dla Zjednoczonego Królestwa pojawiły się dwa zagrożenia geopolityczne. Pierwsze to rosnące ograniczenia suwerenności ze strony Komisji i Trybunału Sprawiedliwości. Drugie to wzrastająca rola Niemiec i Francji w procesach integracyjnych i decyzjach strategicznych w UE ${ }^{15}$. Dlatego w ostatnich latach przed opuszczeniem UE Wielka Brytania w coraz większym stopniu zmuszona była do blokowania polityk europejskich (co było określane jako „negatywne

12 H.D. Clarke, M. Goodwin, P. Whiteley, Brexit. Why Britain Voted to Leave the European Union?, Cambridge 2017; K. Nicolaïdis, The Political Mantra. Brexit, Control and the Transformation of the European Order, [w:] The Law \& Politics of Brexit, red. F. Fabbrini, Oxford-New York 2017, s. $25-48$.

13 Por. P. Mair, Political opposition and the European Union, „Government and Opposition” 42, 2007, nr 1, s. 1-17.

${ }^{14}$ Na podobny temat por. I. Camisão, M.H. Guimarães, The commission, the single market and the crisis: The limits of purposeful opportunism, „Journal of Common Market Studies” 55, 2017, nr 2, s. 223-239; A. Angelou, Turning Crisis into Opportunity? The European Commission's strategy during the Eurozone Crisis, Paris 2018; G. Davies, Does the Court of Justice own the Treaties? Interpretative pluralism as a solution to over-constitutionalisation, „European Law Journal” 24, 2018, nr 6, s. 358-375.

15 Por. W. Münchau, The relentless push towards EU integration, „Financial Times” 28.01.2019, s. 9. 
przywództwo" ${ }^{16}$ ), gdyż był to jedyny sposób na zatrzymanie niekorzystnych dla niej procesów integracyjnych.

Warto zwrócić uwagę na jeszcze inny aspekt procesów integracyjnych, który miał rosnące znaczenie dla stanowiska brytyjskiego. Przykładem tego, o czym myślę, jest kwestia migracji. Pozornie sprawa dotyczyła zbyt dużego napływu imigrantów ekonomicznych ze wschodniej części UE. Dlatego co najmniej od $2015 \mathrm{r}$. Wielka Brytania starała się ograniczyć swobodę przepływu pracowników na rynku wewnętrznym, zwłaszcza w zakresie możliwości korzystania z brytyjskiego systemu społecznego ${ }^{17}$. Prawdopodobnie błędem UE było nieuwzględnienie w wystarczającym stopniu tego brytyjskiego postulatu ${ }^{18}$. Kampania referendalna na temat brexitu zbiegła się z kryzysem migracyjnym w UE, który nie dotyczył migracji na rynku wewnętrznym, a raczej niekontrolowanego napływu do Unii ludności pozaeuropejskiej. Miało to bez wątpienia negatywny wpływ na stanowisko Brytyjczyków o przyszłości integracji. Według Alaina Finkielkrauta, prominentnego intelektualisty francuskiego, gdyby w 2015 r. kanclerz Angela Merkel nie otworzyła granic Unii dla ponad miliona imigrantów i uchodźców, nie byłoby brexitu ${ }^{19}$. Opisywany przykład należy interpretować szerzej. Na Wyspach Unię Europejską zaczęto postrzegać jako element destabilizacji, przynoszący obywatelom coraz więcej kosztów i coraz mniej korzyści, których nie dystrybuowano sprawiedliwie między państwami członkowskimi, co nie podobało się rosnącej liczbie Brytyjczyków ${ }^{20}$.

Problem brexitu polega na tym, że wyjście Zjednoczonego Królestwa z UE nie kończy tych problemów i negatywnego postrzegania procesów integracyjnych przez obywateli. Brexit unaocznił wielu elitom i społeczeństwom w innych krajach członkowskich podstawowe bolączki UE. Okazało się, że coraz większa część narodów Europy kontynentalnej postrzega integrację w podobny sposób co Brytyjczycy. Dlatego wszystkie obawy i problemy, z którymi borykali się obywatele Zjednoczonego Królestwa, pozostają na kontynencie, a po brexicie mogą one z nową siłą uderzyć w Unię Europejską.

16 The United Kingdom and the European Union: What would a "Brexit" mean for the EU and other States around the World?, red. A. Möller, T. Oliver, „The German Council on Foreign Relations” 16, Berlin 2014, s. 2.

17 List premiera Davida Camerona do przewodniczącego Rady Europejskiej Donalda Tuska A New Settlement For The United Kingdom In A Reformed European Union, London, 10 listopada 2015.

18 European Council meeting (18 and 19 February 2016) - Conclusions, EUCO 1/16, Brussels, 19 lutego 2016.

19 M. Karnitschnig, Merkel's go-it-alone legacy. German chancellor's unexpectedly soaring oratory can't make up for years of failed foreign policy, „Politico” 21.02.2019, https://www.politico.eu/article/ angela-merkel-legacy-go-it-alone-germany/ (dostęp: 27 lutego 2019).

20 D. Korski, Dlaczego przegraliśmy głosowanie w sprawie Brexitu?, „Nowa Europa” 2019, nr 1 (21), s. $13-45$. 


\section{Negocjacje}

W trakcie negocjacji dotyczących umowy o wyjściu z UE Brytyjczycy wyraźnie ustępowali stronie unijnej w rokowaniach, przekraczając kilkakrotnie własne „Czerwone linie” negocjacyjne. Strategia Unii Europejskiej w rokowaniach z Wielką Brytanią była klarowna: należy wykorzystać przewagę negocjacyjną i maksymalizować korzyści względem słabszego partnera. Celem Unii było zachowanie spójności rynku wewnętrznego, w tym w zakresie czterech swobód traktatowych (przepływu towarów, osób, usług i kapitału) oraz utrzymanie całej Irlandii (łącznie z Irlandią Północną) w unii celnej. Tym samym chciano wywrzeć presję na Wielkiej Brytanii, aby docelowo pozostała blisko związana z rynkiem wewnętrznym. Przede wszystkim jednak chciano pokazać Brytyjczykom i wszystkim innym nacjom, że wyjście z UE jest znacznie gorszym rozwiązaniem niż pozostanie w niej.

Nieprzypadkowo Manfred Weber - przewodniczący Europejskiej Partii Ludowej w PE i wiodący kandydat tej formacji w wyborach europejskich z 2019 r. na stanowisko szefa Komisji — powiedział na kongresie swojej partii, że obywatele UE muszą zobaczyć, że wyjście z UE jest kosztowne i jest gorszym rozwiązaniem aniżeli dalsze członkostwo ${ }^{21}$. Nic dziwnego, że słabsza w negocjacjach strona brytyjska była coraz bardziej rozczarowana, gdyż nie mogła wynegocjować korzystnych dla siebie zapisów umowy. Dlatego czołowy polityk konserwatywny (i jeden z ministrów spraw zagranicznych z okresu negocjacji omawianej umowy) Jeremy Hunt przyrównał trudności opuszczenia UE do wychodzenia ze Związku Radzieckiego, gdyż jego zdaniem Bruksela szukała możliwości ukarania Brytyjczyków za ich decyzję 22 .

Kolejne koncesje ze strony brytyjskiej przedyskutowano w czasie spotkania rządu na początku lipca 2018 r. w letniej siedzibie premiera - pałacu Chequers. Wśród rządowej partii konserwatywnej zarysowały się dwa główne stanowiska w tej sprawie - pierwsze, które utrzymywało silne związki z UE w ramach unii celnej, które można określić jako „soft brexit” oraz drugie, że skoro nie można wynegocjować z UE korzystnej dla Brytyjczyków umowy, to jedynym planem musi być brexit bez umowy, a więc rozwiązanie "twarde”.

Preferowana przez szefową rządu strategia „soft brexit” nie spodobała się dwóm kluczowym politykom, opowiadającym się za „twardym” brexitem. Wkrótce David Davis, minister odpowiedzialny za negocjacje z Unią, oraz minister spraw zagranicznych Boris Johnson podali się do dymisji. Uznali, że strategia premier Theresy May „oznacza brexit tylko z nazwy”, a faktycznie Wielka Brytania ostatecznie utra-

${ }^{21}$ D.M. Herszenhorn, M. de La Baume, EPP debate: A fight without a single punch thrown, „Politico" 7.11.2018, https://www.politico.eu/article/epp-manfred-weber-alexander-stubb-spitzenkandidat-debate-a-fight-without-a-single-punch-thrown/ (dostęp: 27 lutego 2019).

22 Ch. Cooper, Jeremy Hunt to Brussels: Don't turn EU into 'prison', „Politico” 30.09.2018, https:// www.politico.eu/article/jeremy-hunt-to-brussels-dont-turn-eu-into-prison/ (dostęp: 27 lutego 2019). 
ci suwerenność i stanie się quasi-kolonią UE ${ }^{23}$. Ich zdaniem „miękki” brexit jest sprzeczny z wolą narodu, wyrażoną w referendum. Zachwiało to rządem i posadą samej May. Niemniej premier kontynuowała „miękką” strategię brexitu i wbrew rosnącemu oporowi w łonie partii konserwatywnej opublikowała „białą księgę", w której wyłożyła swoje stanowisko negocjacyjne w rozmowach z Brukselą ${ }^{24}$.

Pytanie o sposób wyjścia Wielkiej Brytanii z UE miało dla przyszłości Europy coraz większe znaczenie geopolityczne. Po pierwsze, od tego zależały przyszłe relacje strategiczne Londynu z Waszyngtonem. W przypadku „hard brexit” mogły one nabrać znaczenia, w przypadku rozwiązania "soft” Wielka Brytania pozostawałaby w orbicie strategicznej Berlina i Paryża. Po drugie, ważyły się losy statusu Brytyjczyków po brexicie - czy zostanie on zmarginalizowany do poziomu Norwegii, odnoszącej wprawdzie korzyści z wymiany gospodarczej z UE, ale niemającej żadnych aspiracji, aby stać się mocarstwem regionalnym. Dla Londynu stawką były nie tylko korzyści ekonomiczne, lecz także własna podmiotowość na arenie międzynarodowej i aspiracje do odgrywania w przyszłości bardziej autonomicznej roli. Po trzecie, pytanie dotyczyło tego, czy brexit wzmocni UE i przywództwo francusko-niemieckie w Europie, czy raczej je naruszy. „Soft brexit” na warunkach Brukseli torował stronie europejskiej drogę do wygrania tego kryzysu. Tymczasem rozwiązanie „twarde” mogło silnie uderzyć w Europę kontynentalną zarówno pod względem strat gospodarczych, jak i osłabienia roli geopolitycznej.

W ten sposób latem $2018 \mathrm{r}$. w pełni objawiła się druga logika geopolityczna, opisywana w niniejszym artykule. Tylko „twardy” brexit realizował pierwotne cele geopolityczne o odzyskaniu podmiotowości i suwerenności, zarówno w wymiarze politycznym, jak i swobody zawierania relacji gospodarczych. Scenariusz „miękkiego" wyjścia z Unii, a więc utrzymujący ścisłe związki z UE na płaszczyźnie ekonomicznej, był wprawdzie korzystny gospodarczo, ale przyczyniał się do pogłębienia zależności Zjednoczonego Królestwa w warstwie regulacyjnej i politycznej od Brukseli, co ograniczało autonomię geopolityczną Londynu jeszcze bardziej niż dotychczasowe członkostwo w UE.

W listopadzie 2018 r. wynegocjowano blisko 600-stronicową umowę o wyjściu Wielkiej Brytanii z UE ${ }^{25}$. Nad Tamizą i w rządzie Theresy May wywołała ona falę krytyki i kilka dymisji. W grudniu 2018 r. Westminster odrzucił umowę miażdżą-

23 T. Colson, A. Bienkov, Boris Johnson accuses Theresa May of seeking 'Brexit in name only' in damning resignation speech, „Business Insider” 18.07.2018, https://www.businessinsider.com/borisjohnson-resignation-speech-theresa-may-brexit-2018-7?IR=T (dostęp: 27 lutego 2019).

24 The future relationship between the United Kingdom and the European Union, HM Government, Cm 9593, July 2018.

25 Agreement on the withdrawal of the United Kingdom of Great Britain and Northern Ireland from the European Union and the European Atomic Energy Community, as endorsed by leaders at a special meeting of the European Council on 25 November 2018, https://assets.publishing.service. gov.uk/government/ (dostęp: 27 lutego 2019). 
cą większością 230 głosów (202 głosów za i 432 przeciw) ${ }^{26}$. W istocie trudno uznać wynegocjowaną propozycję za korzystną dla tych Brytyjczyków, którzy domagali się, aby „brexit oznaczał brexit”, a więc jednoznaczne zerwanie więzów z Brukselą. Największe kontrowersje wzbudzał „backstop”, czyli rozwiązanie awaryjne dotyczące granicy z Irlandią Północną, w sytuacji kiedy obie strony nie byłyby w stanie wynegocjować żadnego porozumienia dotyczącego przyszłych relacji po wyjściu Wielkiej Brytanii z UE. Ponieważ negocjatorzy mieli ogromne problemy w zawarciu listopadowej umowy, „backstop” mógł okazać się w przyszłości trwałym rozwiązaniem normującym relacje obu stron. „Backstop” oznaczał, że całe terytorium Wielkiej Brytanii będzie związane unią celną z UE, ale Irlandia Północna będzie związana znacznie silniej niż pozostała część Wielkiej Brytanii. Oznaczało to, że na Morzu Irlandzkim, a więc w poprzek Wielkiej Brytanii, mogła powstać granica celna dotycząca przynajmniej niektórych towarów i związanych z tym kontroli. Takie rozwiązanie było szczególnie krytykowane przez unionistów z Irlandii Północnej.

Ponadto zgodnie z listopadową umową Wielka Brytania była zmuszona przyjmować dorobek prawa europejskiego (nie uczestnicząc w żaden sposób w jego powstawaniu) dotyczący niektórych obszarów rynku wewnętrznego, m.in. w zakresie ochrony środowiska, standardów socjalnych, pomocy publicznej, konkurencji na rynku wewnętrznym i opodatkowania. $\mathrm{W}$ tych wszystkich sprawach musiała również respektować zwierzchność Trybunału Sprawiedliwości UE, co do tej pory było solą w oku zwolenników brexitu. Co najważniejsze, Wielka Brytania nie mogła wyjść jednostronnie z „backstopu”, co oznaczało, że umowa ewentualnie zastępująca w przyszłości „backstop” byłaby prawdopodobnie jeszcze bardziej niekorzystna dla Wielkiej Brytanii. Na jednym ze szczytów UE prezydent Emmanuel Macron zagroził, że nie zgodzi się na wyjście Wielkiej Brytanii z backstopu, jeśli Brytyjczycy nie dokonają kolejnych ustępstw negocjacyjnych, zwłaszcza zezwalając na dostęp francuskich rybaków do łowisk brytyjskich ${ }^{27}$.

Oprócz tego Londyn nie miałby swobody zawierania umów handlowych $\mathrm{z}$ innymi państwami, np. z USA (z wyjątkiem kwestii inwestycji i usług, które nie były objęte umową celną z UE). Był natomiast w sposób asymetryczny związany wszelkimi umowami handlowymi zawieranymi z państwami trzecimi przez UE. Oznaczało to, że państwa te mogły korzystać na terytorium Wielkiej Brytanii z przywilejów wynegocjowanych z Brukselą, ale sami Brytyjczycy nie mieli korzyści firm europejskich, wynikających z tych umów na terytorium państw trzecich (chyba że Londyn sam by je później wynegocjował w odrębnym porozumieniu).

Umowa z Brukselą zakładała, że o ile towary produkowane w UE miały swobodny dostęp do rynku Wielkiej Brytanii (w ramach tej wymiany strona europejska ma nadwyżkę handlową z UK), o tyle usługi finansowe (gdzie przewagę mają

${ }^{26}$ Ch. Cooper, Historic defeat for Theresa May on Brexit vote, „Politico” 15.01.2019, https://www. politico.eu/article/brexit-deal-rejected-by-432-votes-to-202-2/ (dostęp: 27 lutego 2019).

27 W. Münchau, Brexit goes to the brink, „Financial Times” 11.02.2019, s. 9. 
Brytyjczycy) miały bardzo ograniczony dostęp do terytorium UE. Bankowość komercyjna została wyłączona $\mathrm{z}$ umowy, a pozostałe usługi finansowe mogły zostać dopuszczone do rynku wewnętrznego za zgodą Komisji i tylko na podstawie dyskrecjonalnej procedury porównania standardów prawnych w UE i Wielkiej Brytanii (equivalence decisions).

To wszystko czyniło listopadową umowę niekorzystną dla Brytyjczyków. Nic dziwnego, że niektórzy politycy na Wyspach określali ją jako kapitulację przed presją Brukseli i układ wasalny ${ }^{28}$. Wspomniana umowa, określana także jako rozwodowa, została później jeszcze dwa razy odrzucona przez Westminster (w styczniu i w marcu 2019 r.). Od tego momentu wyjście Zjednoczonego Królestwa bez umowy stało się bardziej prawdopodobne, tym bardziej że stanowisko unijne było mało elastyczne, gdyż odrzucało jakiekolwiek możliwości renegocjowania umowy z Wielką Brytanią (w tym możliwości złagodzenia „backstopu”) ${ }^{29}$.

W sytuacji komplikujących się negocjacji dotyczących wyjścia Zjednoczonego Królestwa z UE pojawiła się trzecia logika geopolityczna. Starała się ona odwrócić brexit, a więc dążyła do pozostania Wielkiej Brytanii w UE. W 2018 r. powstał ruch Głos Narodu (ang. People’s Vote), który dążył do rozpisania ponownego referendum w sprawie brexitu (lub przynajmniej powszechnego głosowania w sprawie finalnej umowy dotyczącej wyjścia Zjednoczonego Królestwa z UE). W 2019 r. pod wpływem silnej presji wewnątrz Partii Pracy lider tego ugrupowania Jeremy Corbyn poparł tę ideę ${ }^{30}$. Zarówno większość jego partii, jak również ruch Głos Narodu sprzeciwili się umowie wynegocjowanej w listopadzie $2018 \mathrm{r}$. przez Theresę May ${ }^{31}$. Zgodnie z moimi założeniami uznali bowiem, że umowa jest gorszym rozwiązaniem od pełnoprawnego członkostwa w UE, co oznaczało poparcie dla drugiego referendum (nawet jeśli w przypadku lidera Partii Pracy było to działanie bardziej koniunkturalne niż zgodne z jego wcześniejszymi deklaracjami programowymi popierającymi brexit ${ }^{32}$ ). Wolta polityczna Corbyna, czyli przejście od wspierania wyjścia z Unii przy zachowaniu unii celnej z rynkiem wewnętrznym do

28 Britain agrees Brexit divorce deal with EU, May's opponents vow to thwart it, "Reuters" 13.11.2018, https://www.reuters.com/article/uk-britain-eu/britain-agrees-brexit-divorce-dealwith-eu-mays-opponents-vow-to-thwart-it-idUSKCN1NIOUN (dostęp: 27 lutego 2019).

${ }^{29}$ Ch. Cooper, D.M. Herszenhorn, UK votes for Brexit renegotiation, Brussels says no, „Politico” 29.01.2019, https://www.politico.eu/article/uk-wants-brexit-backstop-renegotiation-brussels-eu-saysno/ (dostęp: 27 lutego 2019).

${ }^{30}$ K. MacLellan, W. James, UK's Labour says it will back call for second Brexit referendum, „Reuters" 25.02.2019, https://www.reuters.com/article/us-britain-eu-labour-referendum/uks-laboursays-it-will-back-call-for-second-brexit-referendum-idUSKCN1QE25U (dostęp:27lutego 2019).

31 People's vote supporters revel in defeat of May's Brexit deal, „The Guardian” 15.01.2019, https:// www.theguardian.com/politics/2019/jan/15/a-terrible-deal-remainers-and-leavers-unite-againsttheresa-may-brexit-plan (dostęp: 27 lutego 2019).

32 J. Randerson, Jeremy Corbyn sets Labour's terms for Brexit deal support, „Politico” 7.02.2019, https://www.politico.eu/article/jeremy-corbyn-sets-labours-terms-for-brexit-deal-support/ (dostęp: 27 lutego 2019). 
akcentowania przede wszystkim ponownego referendum, jeszcze bardziej zmniejszyła szanse osiągnięcia „miękkiego” brexitu, w tym zwłaszcza na podstawie umowy wynegocjowanej przez Theresę May.

Na kwietniowym szczycie UE przywódcy państw członkowskich ponownie zgodzili się przedłużyć termin wyjścia Zjednoczonego Królestwa do końca października 2019 r. (wcześniej prolongowano tę datę do 22 maja, czyli na dzień przed ewentualnym głosowaniem Brytyjczyków w wyborach do Parlamentu Europejskiego). Do tego czasu premier Theresa May chciała ratyfikować umowę rozwodową z UE (czyli traktat regulujący zasady wyjścia Wielkiej Brytanii z UE), co trzykrotnie się nie udało.

Ostatnią deską ratunku dla May było podjęcie negocjacji z największą parlamentarną siłą opozycyjną, czyli Partią Pracy. Warunkiem ratyfikacji miało być przyjęcie przez konserwatystów założenia, że umowa rozwodowa będzie poddana pod referendum, a ponadto docelowa umowa o relacjach Zjednoczonego Królestwa z UE będzie się opierała na stałej unii celnej. Oba warunki były nie do zaakceptowania przez rząd konserwatystów. Ponadto w rozmowach widać było brak wzajemnego zaufania. Laburzyści wprost zarzucali swoim negocjacyjnym partnerom, że jak tylko ratyfikują umowę rozwodową, to May poda się do dymisji, a kolejny premier nie będzie respektował ustaleń przyjętych z Partią Pracy. Nic więc dziwnego, że rozmowy zostały zerwane tuż przed wyborami do $\mathrm{PE}^{33}$.

Zdesperowana May zapowiedziała, że i tak czwarty raz spróbuje ratyfikować umowę rozwodową $\mathrm{w}$ Westminsterze, a ponadto że zgadza się, aby w ramach ratyfikacji parlament przyjął zobowiązanie o poddaniu tej umowy pod głosowanie w referendum powszechnym. To było za wiele dla wyborców konserwatywnych. Nie podobało się im już to, że May podjęła negocjacje z Partią Pracy, a zgodę na ponowne referendum odebrano jako zawoalowaną formę odwrócenia brexitu. I okazało się to sporym błędem May.

W wyborach do PE w maju 2019 r. konserwatyści ponieśli druzgocącą porażkę, zajmując dopiero piąte miejsce, zdobywając jedynie 9\% głosów i zaledwie cztery mandaty do PE. Jednocześnie całkiem nowa partia Nigela Farage’a, ale popierająca „twardy brexit”, zdobyła ok. 32\% głosów i 29 miejsc w PE ${ }^{34}$. Większość konserwatywnych wyborców, zirytowana kunktatorstwem May, postanowiła zagłosować na partię jednoznacznie popierającą wyjście z UE, co więcej, mającej tylko ten jeden postulat programowy. Był to bez wątpienia jasny sygnał dla partii konserwatywnej. Nic więc dziwnego, że kolejnego dnia po wyborach premier May została zmuszona przez kolegów partyjnych do dymisji, mimo że jeszcze kilka dni wcześniej nie chciała nawet o tym słyszeć.

${ }^{33}$ I. Geoghegan, Brexit talks between Conservatives and Labour collapse, „Politico” 17.05.2019, https://www.politico.eu/article/labour-ends-brexit-talks-with-conservatives/ (dostęp: 27 lutego 2019).

34 T. McTague, Nigel Farage’s new Brexit revolution, „Politico” 27.05.2019, https://www.politico. eu/article/nigel-farages-new-brexit-revolution-tories-eu-election/ (dostęp: 27 lipca 2019). 
Pod koniec lipca 2019 r. Borisa Johnsona wybrano nowym liderem partii konserwatywnej głosami ponad 92 tys. członków tej formacji (66\% biorących udział w wyborach) $)^{35}$. Następnie objął urząd premiera Zjednoczonego Królestwa. Sprowadził swój program wyborczy do trzech głównych haseł: „dostarczyć” brexit, zjednoczyć kraj i pokonać opozycyjną Partię Pracy. Czołowe funkcje w nowym rządzie i parlamencie zajęli zwolennicy opuszczenia UE.

Strona europejska dopuszczała możliwość kolejnego wydłużenia terminu brexitu, co potwierdziła m.in. Ursula von der Leyen ${ }^{36}$. Nowy premier Zjednoczonego Królestwa byl jednak zdeterminowany, aby „dostarczyć” brexit. Zadeklarował nawet, że albo przeprowadzi brexit do końca października 2019 r., „albo zginie" 37 . Szanse wynegocjowania nowej umowy rozwodowej latem 2019 r. były bliskie zeru. Odrzucała to strona unijna, która była gotowa jedynie do modyfikacji niewiążącej deklaracji politycznej dołączonej do tej umowy. Wspomniana umowa w kształcie wynegocjowanym przez May została przez Johnsona nazwana „martwą”. Podstawową kość niezgody, czyli „backstop”, Johnson określił jako „więzienie" 38 . Zapowiedział, że relacje z Irlandią zostaną uregulowane po brexicie. Nowy premier uznał też, że uzgodnione wcześniej przez May transfery finansowe do budżetu UE muszą być renegocjowane. Zadeklarował, że rząd brytyjski zintensyfikuje przygotowania do twardego brexitu, aby społeczeństwo, gospodarka, służba zdrowia i inne służby państwowe były przygotowane na takie rozwiązanie.

Po brexicie strony będą zapewne negocjowały umowę określającą docelowe relacje. To ta umowa była zawsze głównym celem Brukseli, a umowa rozwodowa tylko etapem przejściowym. Johnson nie bez racji zakładał, że wyeliminowanie umowy rozwodowej, a zwłaszcza związanego z nią „backstopu”, daje mu większe pole do negocjacji. Tym samym zwiększa szanse na korzystniejsze zapisy dotyczące umowy docelowej. Temu samemu służyło wycofanie obietnicy ws. finansowania unijnego budżetu w okresie przejściowym. Ponadto negatywne skutki „twardego” brexitu, odczuwane także przez państwa UE, mogły zburzyć dotychczasową jedność krajów członkowskich, a tym samym poprawić pozycję negocjacyjną Zjednoczonego Królestwa.

35 E. Zalan, EU welcomes Johnson by rebuffing his Brexit plans, EUobserver, 23.07.2019, https:// euobserver.com/brexit/145521 (dostęp: 27 lipca 2019).

36 J. Stone, Likely new EU chief open to extending Brexit talks beyond October, letter reveals, „Independent" 15.07.2019, https://www.independent.co.uk/news/uk/politics/brexit-delay-extension-date-ursula-von-der-leyen-letter-a9005016.html (dostęp: 27 lipca 2019).

37 Ch. Cooper, A. Dickson, E. Casalicchio, Boris Johnson's Day 1 revolution, „Politico” 25.07.2019, https://www.politico.eu/article/boris-johnson-day-1-revolution-brexit/ (dostęp: 27 lipca 2019).

${ }^{38} \mathrm{H}$. Yorke, Boris Johnson says he could back Theresa May's deal if she secures a time limit or exit mechanism on Irish backstop, "The Telegraph” 11.02.2019, https://www.telegraph.co.uk/politics/2019/02/11/brexit-latest-news-boris-johnson-softens-opposition-irish/ (dostęp: 27 lipca 2019). 


\section{Konsekwencje}

Brexit osłabi relacje geopolityczne między Zjednoczonym Królestwem a UE. Nawet jeśli Londyn deklarował, że zamierza współpracować z Brukselą w polityce obronnej i sprawach bezpieczeństwa, to będą to więzi znacznie słabsze aniżeli przed opuszczeniem UE. Londyn zapewne jeszcze mocniej zbliży się do Waszyngtonu, pozostawiając sobie jednak możliwości pewnej gry gospodarczej i politycznej z innymi mocarstwami. Przykładem było zabieganie Brytyjczyków o zbliżenie z Pekinem, przynajmniej w sferze ekonomicznej. Wielka Brytania jako pierwszy sojusznik USA zgłosiła akces do Azjatyckiego Banku Inwestycji Infrastrukturalnych, jak również otworzyła się na chińską technologię telekomunikacyjną 5G, w obu przypadkach wyraźnie wbrew stanowisku administracji amerykańskiej ${ }^{39}$. Wbrew polityce prezydenta Donalda Trumpa Londyn popierał w 2019 r. porozumienie nuklearne z Iranem (zawarte w 2015 r.), co więcej, czynił to wspólnie z Francją i Niemcami. Należy to jednak interpretować jako próbę zachowania przez Brytyjczyków autonomii geopolitycznej, ale przy strategicznym pozostawaniu bliskim sojusznikiem USA w sytuacji zapewne stopniowo ochładzających się relacji z UE, Francją i Niemcami.

Wyjście Wielkiej Brytanii z UE, zwłaszcza bez umowy, oznacza pogorszenie sytuacji gospodarczej w strefie euro ${ }^{40}$. Odejście Zjednoczonego Królestwa to cios dla integracji europejskiej, który będzie miał dalekosiężne konsekwencje dla procesów integracyjnych. Przykład brytyjski pokaże innym narodom przede wszystkim to, na co narzekali wcześniej Brytyjczycy. Coraz większa liczba wyborców oczekuje zmiany procesów integracyjnych w podobny sposób jak uprzednio chcieli Brytyjczycy. Jeśli dotychczasowe elity europejskie się nie zreflektują, to scenariusz brytyjski może się w przyszłości powtórzyć w odniesieniu do innych państw. Refleksja powinna dotyczyć sposobu zarządzania procesami integracyjnymi. Oznacza to przede wszystkim ograniczenie roli Komisji Europejskiej i Trybunału Sprawiedliwości, jak również odwrócenia wcześniejszych procesów transferu kompetencji z poziomu narodowego na szczebel UE. Dla UE największym wyzwaniem jest, jak się wydaje, odbudowa demokracji w Europie ${ }^{41}$, co w drugiej dekadzie XXI w. oznaczało konieczność uwzględnienia w większym stopniu uprawnień demokratycznych wspólnot narodowych. Przegłosowywanie tych wspólnot w procesach decyzyjnych w UE byłoby w tym momencie nie tylko naruszeniem demokracji ${ }^{42}$, ale również bardzo ryzykowne dla UE, biorąc pod uwagę tendencje dezintegracyjne w Europie.

39 D. Sevastopulo, D. Bond, Huawei's green light from Britain dents US drive for global 5 G ban, „Financial Times” 18.02.2019, s. 1.

40 Według szacunków niemieckich ekspertów brexit bez umowy może kosztować Niemcy utratę 100 tys. miejsc pracy. H.-U. Brautzsch, O. Holtemöller, Potential international employment effects of a hard Brexit, „IWH-Diskussionspapiere” 2019, nr 4.

41 T.G. Grosse, Pokryzysowa Europa, Warszawa 2018.

42 Por. F.W. Scharpf, De-constitutionalisation and majority rule: A democratic vision for Europe, „European Law Journal” 2017, nr 23, s. 315-334. 
Tymczasem brexit wyzwolił działania ze strony dotychczasowych elit politycznych, które zmierzały w odwrotnym kierunku. Wzmocniło się przywództwo Francji i Niemiec nad procesami integracyjnymi i postulowano zwiększenie spraw głosowanych większościowo w UE, a tym samym możliwość przegłosowywania słabszych politycznie państw ${ }^{43}$. Wzrastała również presja na implementację regulacji europejskich, $w$ tym również w wyniku nacisku ze strony Komisji i Trybunału Sprawiedliwości. Przywództwo francusko-niemieckie zamierzało przyspieszyć procesy integracji, zwłaszcza w polityce obronnej i zagranicznej, jak również kontynuować przenoszenie kompetencji w polityce migracyjnej na poziom europejski. Oba kraje zamierzały przemodelować rynek wewnętrzny, częściowo odchodząc od traktatowych czterech swobód i zwiększając skalę protekcjonizmu dla największych korporacji narodowych (zwłaszcza francuskich i niemieckich ${ }^{44}$ ). Starały się też narzucić innym państwom członkowskim swoje rozwiązania w zakresie rynku pracy i standardów socjalnych, bez względu na ich mniejsze zdolności fiskalne lub bardziej liberalny model funkcjonowania krajowej gospodarki ${ }^{45}$. Można się również spodziewać silniejszej presji na wejście do strefy euro, wywieranej na tych członków UE, którzy dotychczas pozostawali poza tymi strukturami.

Tego rodzaju tendencje polityczne ze strony Paryża i Berlina zapewne pogłębią podziały w UE. Brexit wyraźnie uwidocznił rozłam wewnątrz strefy euro na bardziej konkurencyjne gospodarczo państwa Północy oraz zadłużone i słabiej rozwijające się kraje Południa oraz silny podział na Europę Zachodnią i Środkową, przede wszystkim w odniesieniu do przyszłości polityki migracyjnej. Różnice między Francją i Niemcami mogą być rozgrywane przez Berlin w celu poszukiwania wsparcia ze strony mniejszych państw członkowskich ${ }^{46}$, ale nie wiadomo, czy tego typu działania poprawią skuteczność zarządzania w UE. Co więcej, podziały wewnętrzne objęly również poszczególne państwa członkowskie, w tym także Francję i Niemcy, co może dodatkowo utrudnić plany dotychczasowych elit proeuropejskich.

Odnośnie do brexitu widać było kilka ważnych tendencji geopolitycznych. Przede wszystkim UE straci swoją największą potęgę wojskową i drugą gospodarkę, co wyraźnie osłabi Wspólnotę. Przejawem tej słabości będzie zapewne to, że kolejny wieloletni budżet UE będzie mniejszy niż przed brexitem. Ponadto nasili się spór gospodarczy i geopolityczny Europy Zachodniej z USA. Bez Brytyjczyków „na pokładzie” konflikt ten zapewne jeszcze się wzmocni ${ }^{47}$. Coraz więcej państw członkowskich, w tym również Francja i Niemcy, zmierzało do unormowania relacji geopolitycznych z Rosją, a wyjście Brytyjczyków ze Wspólnoty może ten proces tylko przyspieszyć.

43 G. Grosse, Prognoza dla Europy, „Rocznik Strategiczny” 23, 2017/2018, s. 315-326.

44 G. Chazan, EU urged to protect tech from rivals, „Financial Times” 18.02.2019, s. 3.

45 T.G. Grosse, Social Europe or more protectionist one? The single market in the aftermath of the crises [w druku].

${ }^{46}$ E. Turner, S. Green, Priorytety, kwestie drażliwe, obawy - postrzeganie Brexitu w Niemczech i w Europie Środkowej, „Nowa Europa” 2019, nr 1 (21), s. 99-122.

47 Por. T. Oliver, M.J. Williams, Special relationships in flux: Brexit and the future of the US-EU and US-UK relationships, „International Affairs” 92, 2016, nr 3, s. 547-567. 


\section{Podsumowanie}

W sierpniu 2019 r., kiedy powstawał ten tekst, perspektywa wyjścia Zjednoczonego Królestwa z UE nie była jeszcze w pełni klarowna. Wiadomo było tylko, że proces ten jest bardzo żmudny, trudny politycznie i przeciąga się. Wynikało to m.in. z tego, że po stronie brytyjskiej uwidocznily się sprzeczne cele i logiki geopolityczne, natomiast po stronie unijnej brakowało elastyczności negocjacyjnej i wyrozumiałości dla sytuacji wewnętrznej w Wielkiej Brytanii. Twarde stanowisko negocjacyjne Brukseli zwiększyło szanse „twardego” brexitu, a więc opuszczenia UE przez Zjednoczone Królestwo bez umowy. Uprawdopodabniały to również pierwsza i druga logika geopolityczna elit brytyjskich, które omówiono w niniejszym artykule. Pierwsza zakładała, że suwerenność i racja stanu Zjednoczonego Królestwa są w coraz większym stopniu ograniczane przez procesy integracji europejskiej. Takie przekonanie legło u podstaw całego omawianego procesu, a także skutkowało tym, że scenariusz brexitu wydawał się w 2019 r. najbardziej prawdopodobny, jeśli nie przesądzony. Druga logika geopolityczna zakładała, że w wyniku negocjacji ze stroną europejską jedynie „twardy” scenariusz rozstania umożliwia zrealizowanie pierwotnych założeń brexitu, a więc odzyskania podmiotowości i suwerenności geopolitycznej, dlatego w 2019 r. to właśnie ten scenariusz wydawał się najbardziej realny, mimo że niósł z sobą oczywiste konsekwencje dla strony zarówno brytyjskiej, jak i unijnej (w tym dla największych państw członkowskich ${ }^{48}$ ). Wreszcie trzecia logika geopolityczna polegała na „odwróceniu” brexitu, czyli utrzymaniu Zjednoczonego Królestwa jako pełnoprawnego członka UE. Wskazana logika wyraźnie odbiegała od wymienionych racjonalności geopolitycznych i wydawała się aktem desperacji w sytuacji niemożności wynegocjowania z Brukselą korzystnej umowy o wyjściu z UE. Po wyborach do PE scenariusz pozostania Wielkiej Brytanii w strukturach unijnych wydawał się najmniej prawdopodobny.

\section{Bibliografia}

Agnew J., Geopolitics. Re-visioning World Politics, London-New York 2003.

Agreement on the withdrawal of the United Kingdom of Great Britain and Northern Ireland from the European Union and the European Atomic Energy Community, as endorsed by leaders at a special meeting of the European Council on 25 November 2018, https://assets.publishing.service.gov.uk/government/.

Angelou A., Turning Crisis into Opportunity? The European Commission's strategy during the Eurozone Crisis, Paris 2018.

Brautzsch H.-U., Holtemöller O., Potential international employment effects of a hard brexit, „IWHDiskussionspapiere" 2019, $\mathrm{nr} 4$.

Britain agrees Brexit divorce deal with EU, May's opponents vow to thwart it, „Reuters” 13.11.2018, https:// www.reuters.com/article/uk-britain-eu/britain-agrees-brexit-divorce-deal-with-eu-mays-opponents-vow-to-thwart-it-idUSKCN1NIOUN.

48 H.-U. Brautzsch, O. Holtemöller, op. cit. 
Cameron D., A New Settlement For The United Kingdom In A Reformed European Union, London, 10 listopada 2015.

Camisão I., Guimarães M.H., The commission, the sngle market and the crisis: The limits of purposeful opportunism, „Journal of Common Market Studies” 55, 2017, nr 2.

Chazan G., EU urged to protect tech from rivals, „Financial Times” 18.02.2019.

Clarke H.D., Goodwin M., Whiteley P., Brexit. Why Britain Voted to Leave the European Union?, Cambridge 2017.

Colson T., Bienkov A., Boris Johnson accuses Theresa May of seeking 'Brexit in name only' in damning resignation speech, „Business Insider” 18.07.2018, https://www.businessinsider.com/boris-johnsonresignation-speech-theresa-may-brexit-2018-7? IR=T.

Cooper Ch., Historic defeat for Theresa May on Brexit vote, „Politico” 15.01.2019, https://www.politico.eu/article/brexit-deal-rejected-by-432-votes-to-202-2/.

Cooper Ch., Jeremy Hunt to Brussels: Don't turn EU into 'prison', „Politico” 30.09.2018, https://www. politico.eu/article/jeremy-hunt-to-brussels-dont-turn-eu-into-prison/.

Cooper Ch., Herszenhorn D.M., UK votes for Brexit renegotiation, Brussels says no, „Politico” 29.01.2019, https://www.politico.eu/article/uk-wants-brexit-backstop-renegotiation-brussels-eu-says-no/.

Cowen D., Smith N., After geopolitics? From the geopolitical social to geoeconomics, "Antipode” 41, 2009, nr 1.

Cooper Ch., Dickson A., Casalicchio E., Boris Johnson's Day 1 revolution, „Politico” 25.07.2019, https://www.politico.eu/article/boris-johnson-day-1-revolution-brexit/.

Davies G., Does the Court of Justice own the Treaties? Interpretative pluralism as a solution to over-constitutionalisation, „European Law Journal” 24, 2018, nr 6.

Euro zone February factory activity declined, overall growth scant: PMI, „Reuters” 21.02.2019, https:// www.reuters.com/article/us-eurozone-economy-pmi/euro-zone-february-factory-activity-declined-overall-growth-scant-pmi-idUSKCN1QA102.

European Council meeting (18 and 19 February 2016) - Conclusions, EUCO 1/16, Brussels, 19 lutego 2016.

Fabbrini F., The Law \& Politics of Brexit, Oxford-New York 2017.

Flint C., Introduction to Geopolitics, New York-London 2012.

The future relationship between the United Kingdom and the European Union, HM Government, Cm 9593, July 2018.

Glencross A., Why the UK Voted for Brexit. David Cameron's Great Miscalculation, London-New York 2016.

Gray C.S., Sloan G., Why Geopolitics?, [w:] Geopolitics, Geography and Strategy, red. C.S. Gray, G. Sloan, London-Portland 1999.

Green D.A., Brexit. What Everyone Needs to Know, Oxford-New York 2019.

Grosse T.G., Pokryzysowa Europa, Warszawa 2018.

Grosse T.G., Prognoza dla Europy, „Rocznik Strategiczny” 23, 2017/2018.

Grosse T.G., Social Europe or more protectionist one? The single market in the aftermath of the crises [w druku].

Herszenhorn D.M., de La Baume M., EPP debate: A fight without a single punch thrown, „Politico” 7.11.2018, https://www.politico.eu/article/epp-manfred-weber-alexander-stubb-spitzenkandidat-debate-a-fight-without-a-single-punch-thrown/.

Karnitschnig M., Merkel's go-it-alone legacy. German chancellor's unexpectedly soaring oratory can't make up for years of failed foreign policy, „Politico” 21.02.2019, https://www.politico.eu/article/ angela-merkel-legacy-go-it-alone-germany/.

Korski D., Dlaczego przegraliśmy głosowanie w sprawie Brexitu?, „Nowa Europa” 2019, nr 1 (21).

Łastawski K., Polska racja stanu po wstąpieniu do Unii Europejskiej, Warszawa 2009.

MacLellan K., James W., UK's Labour says it will back call for second Brexit referendum, „Reuters” 25.02.2019, https://www.reuters.com/article/us-britain-eu-labour-referendum/uks-labour-says-it-will-back-call-for-second-brexit-referendum-idUSKCN1QE25U. 
Macron defends the idea of European sovereignty, European Parliament, ref.: 20180411IPR01517, Brussels 17.04.2018.

Mair P., Political opposition and the European Union, „Government and Opposition” 42, 2007, nr 1.

McTague T., Nigel Farage's new Brexit revolution, „Politico” 27.05.2019, https://www.politico. eu/article/ Merkel: EU states must prepare to hand national sovereignty over to Brussels, „Canada Free Press” 24.11.2018, https://canadafreepress.com/article/merkel-eu-states-must-prepare-to-hand-national-sovereignty-over-to-brussels.

Münchau W., Brexit goes to the brink, „Financial Times” 11.02.2019.

Münchau W., The relentless push towards EU integration, „Financial Times” 28.01.2019.

Nicolaidis K., The Political Mantra. Brexit, Control and the Transformation of the European Order, [w:] The Law \& Politics of Brexit, red. F. Fabbrini, Oxford-New York 2017.

nigel-farages-new-brexit-revolution-tories-eu-election/.

Oliver T., Williams M.J., Special relationships in flux: Brexit and the future of the US-EU and US-UK relationships, „International Affairs” 92, 2016, nr 3.

People's vote supporters revel in defeat of May's Brexit deal, „The Guardian” 15.01.2019, https://www. theguardian.com/politics/2019/jan/15/a-terrible-deal-remainers-and-leavers-unite-against-theresa-may-brexit-plan.

Randerson J., Jeremy Corbyn sets Labour's terms for Brexit deal support, „Politico” 7.02.2019, https:// www.politico.eu/article/jeremy-corbyn-sets-labours-terms-for-brexit-deal-support/.

Sadowski E., Racja stanu w polityce zagranicznej państwa, [w:] Wstęp do teorii polityki zagranicznej państwa, red. R. Zięba, Warszawa 2004.

Scharpf F.W., De-constitutionalisation and majority rule: A democratic vision for Europe, „European Law Journal" 2017, nr 23.

Sevastopulo D., Bond D., Huawei's green light from Britain dents US drive for global 5G ban, „Financial Times" 18.02.2019.

Stone J., Likely new EU chief open to extending Brexit talks beyond October, letter reveals, „Independent" 15.07.2019?, https://www.independent.co.uk/news/uk/politics/brexit-delay-extension-date-ursula-von-der-leyen-letter-a9005016.html.

Tuathail G.Ó, General Introduction. Thinking Critically about Geopolitics, [w:] The Geopolitics Reader, red. G.Ó Tuathail, S. Dalby, P. Routledge, London-New York 2006.

Turner E., Green S., Priorytety, kwestie drażliwe, obawy — postrzeganie Brexitu w Niemczech i w Europie Środkowej, „Nowa Europa” 2019, nr 1 (21).

The United Kingdom and the European Union: What would a "Brexit" mean for the EU and other States around the World?, red. A. Möller, T. Oliver, „The German Council on Foreign Relations” 16, Berlin 2014.

Yorke H., Boris Johnson says he could back Theresa May's deal if she secures a time limit or exit mechanism on Irish backstop, „The Telegraph” 11.02.2019, https:/www.telegraph.co.uk/politics/2019/02/11/brexit-latest-news-boris-johnson-softens-opposition-irish/.

Zalan E., EU welcomes Johnson by rebuffing his Brexit plans, EUobserver, 23.07.2019, https://euobserver.com/brexit/145521.

Rocznik Europeistyczny 4, 2018

(C) for this edition by CNS 